\title{
A Short and Efficient Enantioselective Synthesis of (+) and (-)-(Z)-7,15-hexadecadien-4-olide. The Sex Pheromone of the Yellowish Elongate Chafer, Heptophylla picea
}

\author{
Giuliano C. Clososki, Luis C. Ricci, Carlos E. Costa and João V. Comasseto* \\ Instituto de Química, Universidade de São Paulo, Av. Prof. Lineu Prestes, 748, 05508-900 São Paulo - SP, Brazil \\ Os enantiômeros $(R)$ e $(S)$ da Z-7,15-hexadecadien-4-olida (4), o feromônio sexual da Heptophylla \\ picea foram sintetizados. Na etapa chave foi utilizada uma enantiolactonização já conhecida, \\ intermediada por uma lipase, levando a um precursor comum de ambos enantiômeros do feromônio \\ em $92 \%$ de e.e. \\ The $(R)$ and the $(S)$ enantiomers of the Z-7,15-hexadecadien-4-olide (4), the sex pheromone of \\ Heptophylla picea, were synthesized. A known lipase-catalysed enantiolactonization in the key step \\ afforded a common precursor for both enantiomers of the pheromone in $92 \%$ e.e.
}

Keywords: pheromone, Heptophylla picea, lipase

\section{Introduction}

Several classes of compounds such as pheromones, ${ }^{1}$ aromas $^{2,3}$ and plant growth regulators ${ }^{4}$ exhibit a $\gamma$ butyrolactone unity in their structures. Since the biological activity of such compounds often dependes on their absolut configuration, much work has been done to develop enantioselective routes to $\gamma$-butyrolactones. ${ }^{5}$

Recently we initiated a program aiming at the synthesis of enantiomericaly pure naturally occurring lactones using enzymes in a deracemization step. ${ }^{6-8} \mathrm{~A}$ versatile protocol introduced by us consists in the application of a methodology developed by Gutmam and coworkers, which transforms the commercially available 4-ketopimelic acid (1) into the chiral lactone $(S)-(-)-2$, which was transformed in our laboratory into both $(S)^{7}$ and $(R)^{8}$ isomers of jasmolactone $\mathbf{3}$, a compound with organoleptic properties, described as fruity, flowery, green, creamy, sweet and juicy ${ }^{3}$ (Scheme 1).

This strategy is interesting since the common intermediate $\mathbf{2}$ can lead to both enantiomers of a naturaly occurring $\gamma$-butyrolactone. The female sex pheromone of the Yellowish Elongate Chafer (Heptophylla picea) $(4)^{9}$ would be a good candidate to demonstrate the versatility of our methodology.

Compound $(R)-\mathbf{4}$ was prepared by Leal and coworkers in 14 steps starting from L-malic acid..$^{9,10}$ Mori and Nakayama obtained $(R)-\mathbf{4}$ and $(S)-\mathbf{4}$ in respectively $95 \%$

*e-mail: jvcomass@iq.usp.br

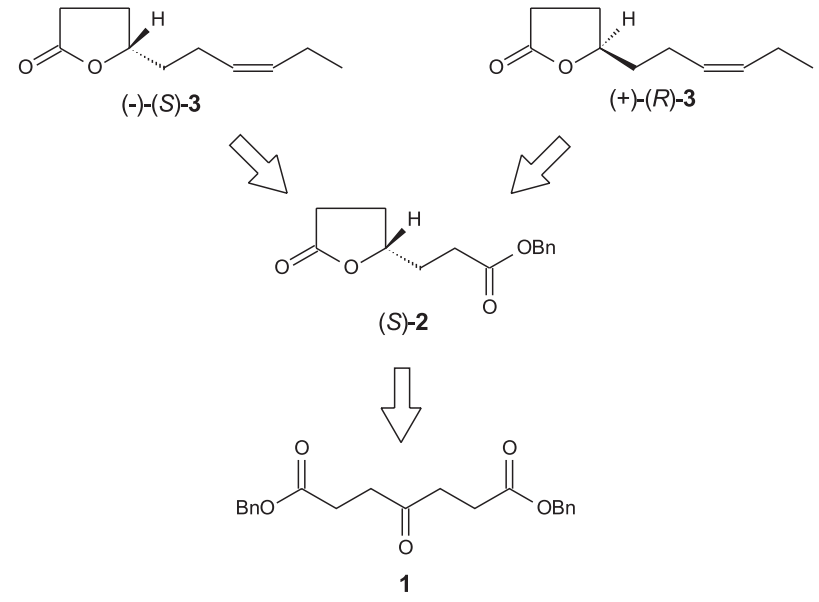

Scheme 1.

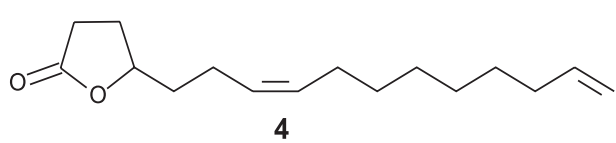

Figure 1. (Z)-7,15-hexadecadien-4-olide.

and $94 \%$ e.e. through an enzymatic resolution of racemic $\mathbf{4}$ using different enzymes in more than one enzymatic step. ${ }^{10,11}$

\section{Results and Discussion}

Scheme 2 shows the retrosynthetic analysis for $(R)$ and $(S)$-(Z)-7-15-hexadecadien-4-olide (4) using our approach. 
(S)-4

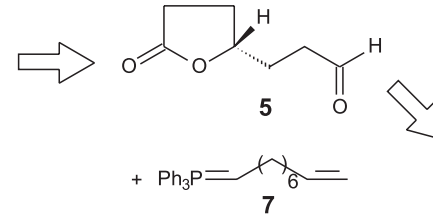<smiles>COC(=O)CC[C@H]1CCC(=O)O1</smiles>

$(R)-4$<smiles>O=C(CC[C@@H]1CC[C@@H](O)O1)O[Ga]1C=CC2CC21</smiles>

Scheme 2.

Compound (S)-2 would be transformed into aldehyde 5 or into lactol 6, which upon reaction with the Wittig reagent $\mathbf{7}$ would give $(S)-\mathbf{4}$ and $(R)-\mathbf{4}$.

The synthesis of $(S)$ - $\mathbf{4}$ started with the reduction of 4 ketopimelic benzyl ester as described previously (Scheme 3). ${ }^{7,12}$ The obtained alcohol $\mathbf{8}$ was submitted to enantioselective lactonization by PPL leading to $(S)-\mathbf{2}$ in $92 \%$ e.e. ${ }^{12}$ The $(S)$ configuration of the lactone 2 was attributed by comparision of its specific rotation, $[\alpha]_{\mathrm{D}}{ }^{20}=$ $-32,7\left(\mathrm{c}=1.04 ; \mathrm{CH}_{2} \mathrm{Cl}_{2}\right)$, with the literature value, $[\alpha]_{\mathrm{D}}^{25}=$ $-40,86\left(\mathrm{c}=0.74 ; \mathrm{CH}_{2} \mathrm{Cl}_{2}\right),{ }^{12}$ and its enantiomeric excess was determined by means of chiral HPLC. ${ }^{7}$ Transformation of the ester function of (S)-2 into an aldehyde was achieved by deprotection of the benzyl group followed by reduction with borane-methyl sulfide complex (BMS) and oxidation with pyridinium chlorochromate (PCC) ${ }^{7,12}$ Using this procedure, the integrity of the stereogenic center was preserved and $(S)-\mathbf{5}$ was the product (Scheme 3).

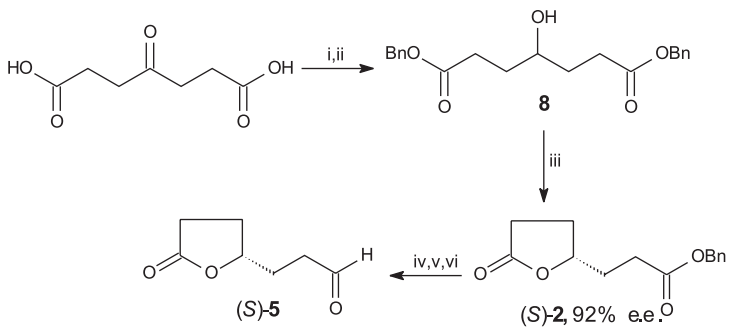

Reagents and conditions:
(i) $\mathrm{CrCO} 3 \mathrm{DMF} / \mathrm{MeOH}, \mathrm{pH} 7.0, \mathrm{BnBr}$, r. t., $17 \mathrm{~h}$ (84\%); (ii) $\mathrm{NaBH} 4, \mathrm{Et} 2 \mathrm{O} / \mathrm{MeOH},-20^{\circ} \mathrm{C}, 2 \mathrm{~h}(95 \%)$; (iii) $\mathrm{PPL}, \mathrm{Et} 2 \mathrm{O}, 30^{\circ} \mathrm{C}, 24 \mathrm{~h}(74 \%)$; (iv) $\mathrm{Pd} / \mathrm{C} \mathrm{C} 10 \%, \mathrm{H} 2$, 1 atm, $3 \mathrm{~h}(95 \%)$; (v) $\mathrm{BMS}$, THF, r. t., $2 \mathrm{~h}(90 \%)$; (vi) $\mathrm{PCC}, \mathrm{CH} 2 \mathrm{Cl} 2$, r. t., $2 \mathrm{~h}(90 \%)$.

Scheme 3.

The lactol $\mathbf{6}$ was prepared by reduction of $(S)-\mathbf{2}$ with a slight excess of DIBAL-H in THF at $-78{ }^{\circ} \mathrm{C}$ as previously reported $^{8}$ (Scheme 4).

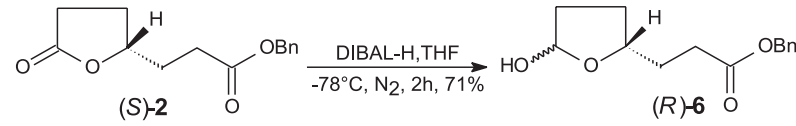

The phosphonium salt $\mathbf{1 2}$, precursor of the Wittig reagent $\mathbf{7}$, was obtained starting from the commercially available 6-bromo-1-hexanol 9 , which upon treatment with allylmagnesium bromide in THF in the presence of dilithium tetrachlorocuprate gave 8-nonenol 10 (Scheme 5). The bromide 11 was prepared by treating 10 with triphenylphosphine bromine complex in acetonitrile. The phosphonium salt $\mathbf{1 2}$ was prepared by refluxing triphenylphosphine and $\mathbf{1 1}$ in acetonitrile. ${ }^{10}$

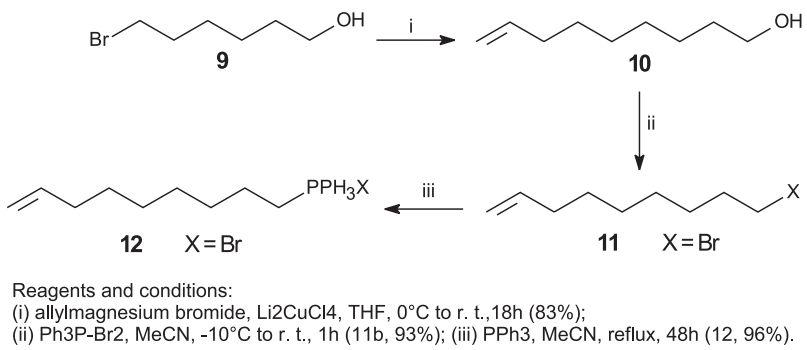

Scheme 5.

The Wittig reagent 7 was obtained by treatment of the phosphonium bromide $\mathbf{1 2}$ with sodium hexamethyldisilazide in THF at $-40{ }^{\circ} \mathrm{C}$ and then reacted with $\mathbf{5}$ or $\mathbf{6}$ to give $(S)-\mathbf{4}$ and $(R)-\mathbf{4}$, respectively, in $92 \%$ e.e. (Scheme 6).

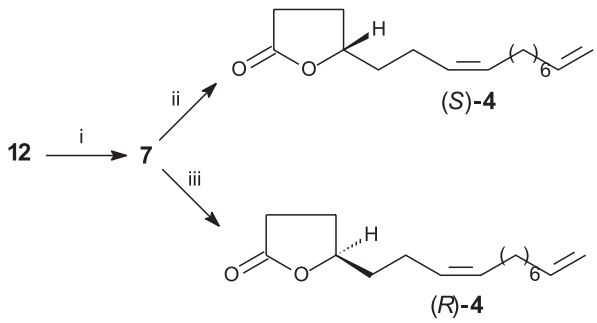

Reagents and conditions:

(i) NaHMDS, THF, $-40^{\circ} \mathrm{C}$; (ii) (S) $-5, \mathrm{THF},-100^{\circ} \mathrm{C}, 1.5 \mathrm{~h}(60 \%$, Z/E = 96:4, $92 \%$ e.e.); (iii) (R)-6, THF, $-100^{\circ} \mathrm{C}, 1.5 \mathrm{~h}(55 \%$, $\mathrm{Z} / \mathrm{E}=96: 4,92 \%$ e.e. $)$

Scheme 6 .

For preparation of compound $(R)-\mathbf{4}$, two equivalents of 7 were used. The first equivalent deprotonates the $\mathrm{OH}$ group opening the lactol ring and the second transforms the aldehyde into an olefine. The alkoxy oxygen at $\mathrm{C}_{4}$ promotes a transesterification reaction of the benzyl ester group generating the lactone ring of $(R)-\mathbf{4}$ (Scheme 7).

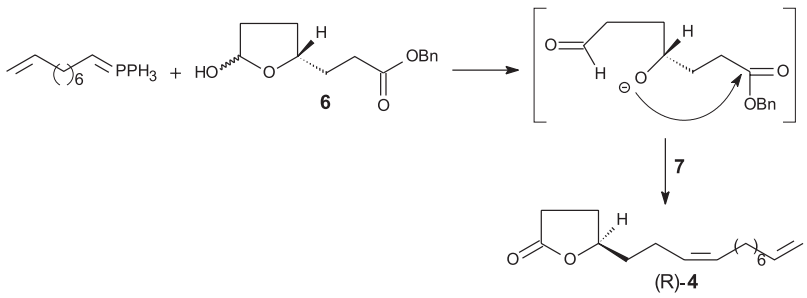

Scheme 7 
Compounds $(S)-\mathbf{4}$ and $(R)-\mathbf{4}$ were obtained as $Z / E$ mixtures (96:04), which were purified by column chromatography on silica gel impregnated with $\mathrm{AgNO}_{3}$ to afford the desired products in pure form. The absolute configuration of both enantiomers was attributed by comparing the $[\alpha]^{\mathrm{D}}$ values of our products with those reported in the literature. ${ }^{10}$ Attempts to determine the enantiomeric excess of $(S)-\mathbf{4}$ and $(R)-\mathbf{4}$ by chiral gas chromatography were unsuccessful. In view of this failure compounds $(S)-\mathbf{4}$ and $(R)-\mathbf{4}$ were hydrogenated using $\mathrm{Pd} /$ $\mathrm{C}$ as catalyst and the products were analysed by chiral GC using a $\beta$-cyclodextrine as a chiral phase on a capillary column. This analysis showed that both $(S)-\mathbf{4}$ and $(R)-\mathbf{4}$ were obtained with $92 \%$ e.e. (Figure 2).
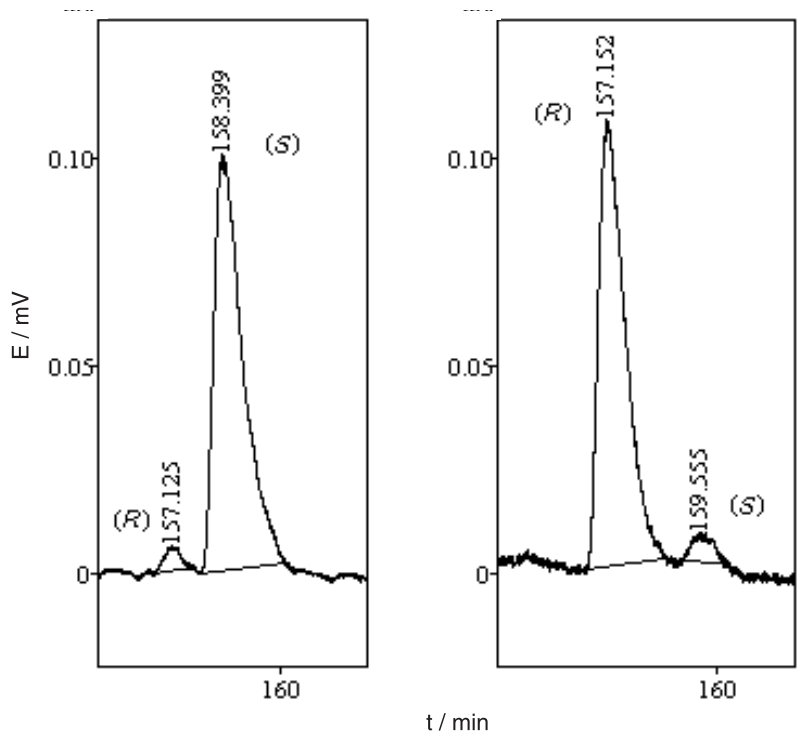

Figure 2. Chiral chromatograms of hydrogenated (S)-4 and (R)-4.

In conclusion, $(S)$ and $(R)-(Z)-7,15$-hexadecadien-4olide (4) were obtained in high enantiomeric excess in 4 and 3 steps respectively, starting from the easily prepared common intermediate $(S)$-2. With the completion of this synthesis we showed that $(S)$-2 is a versatile precursor of both enantiomers of naturally occurring $\gamma$-butyrolactones.

\section{Experimental}

\section{General experimental procedures}

The NMR spectra were recorded on Brucker DRX-500, Varian Inova ( $300 \mathrm{MHz}$ ) and Brucker AC-200 spectrometers using TMS ( ${ }^{1} \mathrm{H}$ NMR) and the central peak of the $\mathrm{CDCl}_{3}$ signal $\left({ }^{13} \mathrm{C}\right.$ NMR $)$ as internal reference. IR spectra were obtained with a FTIR Bomem MB100 grating infrared spectrophotometer. The GC analysis were performed on a Hewlett-Packard 5890(II) instrument with a capillary crosslinked 5\% Ph-Me silicone column (25 m x $0.20 \mathrm{~mm}$ $\mathrm{x} 0.33 \mu \mathrm{m})$ and on a Shimadzu GC-17A instrument equipped with a Chirasil-DEX CD (Crompack) chiral phase capillary column ( $30 \mathrm{~m} \times 0.25 \mathrm{~mm} \times 0.25 \mu \mathrm{m})$. The mass spectra were performed on a Shimadzu GC-17A/QP5050A spectrometer. Optical rotations were measured on a Jasco, DIP 370 digital polarimeter. The enzymatic reactions were monitored in a Shimadzu LC10AD HPLC. 8-Nonen-1-ol (10) and 9-bromo-1-nonene (11) were prepared as described in the literature. ${ }^{10}$

Triphenyl-(8-noneyl)-phosphonium bromide, (12)

A solution of 9-bromo-1-nonene, (11) (0.97 g, 4.72 mmol) and triphenylphosphine $(1.78 \mathrm{~g}, 6.80 \mathrm{mmol})$ in acetonitrile $(12 \mathrm{~mL})$ was refluxed for $24 \mathrm{~h}$ under Ar. The acetonitrile was concentrated in vacuo, and the excess of $\mathrm{PPh}_{3}$ was removed by chromatography on silica gel eluting with ethyl acetate / methanol $(80: 20)$ to give $2.12 \mathrm{~g}(96 \%)$ of the phosphonium salt $\mathbf{1 2}$ as a gum. ${ }^{1} \mathrm{H} \mathrm{NMR}\left(\mathrm{CDCl}_{3}\right.$, $200 \mathrm{MHz}$ ): $\delta 1.25$ (br. s, 6H), 1.63 (m, 4H), 1.92-1.95 (m, 2H), 3.71 (br. s, 2H), 4.86-5.0 (m, 2H), 5.73 (ddt, $J 16.7 \mathrm{~Hz}$, $10.1 \mathrm{~Hz}$ and $6.58 \mathrm{~Hz}, 1 \mathrm{H}), 7.60-7.90(\mathrm{~m}, 15 \mathrm{H})$; IR $(\mathrm{KBr})$ $v_{\max } / \mathrm{cm}^{-1}: 2932,1431,1104,996,733,687,521$.

\section{(S)-7,15-Hexadecadien-4-olide, [(S)-4]}

To a solution of the dry phosphonium salt $12(0.25 \mathrm{~g}$, $0.53 \mathrm{mmol})$ in dry THF $(4 \mathrm{~mL})$ NaHDMS $(0.58 \mathrm{~mL}, 0.58$ mmol, $1 \mathrm{M}$ THF solution) was added at $-40{ }^{\circ} \mathrm{C}$ under Ar. After $10 \mathrm{~min}$ of stirring at the same temperature, the resulting orange solution was transferred via canula to a solution of the aldehyde $5(0.071 \mathrm{~g}, 0.5 \mathrm{mmol})$ in dry THF $(4 \mathrm{~mL})$ at $-78^{\circ} \mathrm{C}$ under Ar. After stirring for $90 \mathrm{~min}$ at the same temperature, the reaction mixture was quenched with saturated $\mathrm{NH}_{4} \mathrm{Cl}$ solution. The organic layer was separated, and the aqueous layer was extracted with diethyl ether. The organic layer was washed with water and brine, dried with $\mathrm{MgSO}_{4}$ and concentrated in vacuo. The crude product was purified by chromatography in silica gel impregnated with $\mathrm{AgNO}_{3}$ eluting with pentane/diethyl ether $(2: 1)$ to give $0.074 \mathrm{~g}(60 \%)$ of the $(S)$-7,15-hexadecadien-4-olide [(S)-4]. ${ }^{1} \mathrm{H}$ NMR $\left(\mathrm{CDCl}_{3}, 500 \mathrm{MHz}\right): \delta 1.21-1.4(\mathrm{~m}, 8 \mathrm{H})$, 1.5-1.7 (m, 1H), 1.75-1.91 (m, 2H), 2.00-2.08 (m, 4H), 2.16$2.22(\mathrm{~m}, 2 \mathrm{H}), 2.33$ (ddt, $J 13.3 \mathrm{HZ}, 6.8 \mathrm{HZ}$ and $6.4 \mathrm{~Hz}, 1 \mathrm{H}$ ), $2.53(\mathrm{~m}, 2 \mathrm{H}), 4.50$ (ddt, $J 7.9 \mathrm{~Hz}, 6.7 \mathrm{~Hz}$ and $5.3 \mathrm{~Hz}, 1 \mathrm{H}$ ), 4.9 (ddt, $J 10.2 \mathrm{~Hz}, 3.3 \mathrm{~Hz}$ and $1.2 \mathrm{~Hz}, 1 \mathrm{H}$ ), 4.98 (ddt, $J$ $17.2 \mathrm{~Hz}, 13.6 \mathrm{~Hz}$ and $1.6 \mathrm{~Hz}, 1 \mathrm{H}), 5.35$ (ddt, $J 12.3 \mathrm{~Hz}, 7.2$ $\mathrm{Hz}$ and $1.4 \mathrm{~Hz}, 1 \mathrm{H}$ ), 5.45 (ddt, $J 12.3 \mathrm{~Hz}, 7.2 \mathrm{~Hz}$ and $1.4 \mathrm{~Hz}$, 
1H), 5.8 (ddt, $J 17.4 \mathrm{~Hz}, 10.3 \mathrm{~Hz}$ and $5.7 \mathrm{~Hz}, 1 \mathrm{H}$ ); ${ }^{13} \mathrm{C} \mathrm{NMR}$ $\left(\mathrm{CDCl}_{3}, 50 \mathrm{MHz}\right) \delta 23.4,27.4,28.2,29.0,29.1,29.3,29.4$, 29.8, 34.0, 35.9, 80.6, 114.4, 127.9, 131.7, 139.4, 177.4; IR $(\mathrm{KBr}) v_{\max } / \mathrm{cm}^{-1}: 3104,1775,1667,1452,1362,1177$, 906; MS (m/z) (\%rel): 41 (100), 55 (83.3), 67 (99.5), 79 (72.7), 93 (44.8), 107 (24.7), 121 (27.9), 135 (19), 150 (30.8), 166 (4), 177 (2.3), 190 (1.3), 207 (1.3); [a $]_{D}^{25}:-34.8$ $\left(c=0.5, \mathrm{CHCl}_{3}\right)$.

\section{(R)-7,15-Hexadecadien-4-olide, [(R)-4]}

To a solution of the dry phosphonium salt $12(0.568 \mathrm{~g}$, $1.06 \mathrm{mmol})$ in dry THF (8 mL) NaHDMS (1.16 mL, 1.16 mmol, $1 \mathrm{~mol} \mathrm{~L}{ }^{-1} \mathrm{THF}$ solution) was added at $-40{ }^{\circ} \mathrm{C}$ under Ar. After $10 \mathrm{~min}$ of stirring the same temperature, the resulting orange solution was transferred via canula to a solution of lactol $6(0.125 \mathrm{~g}, 0.5 \mathrm{mmol})$ in dry THF $(4 \mathrm{~mL})$ at $-78{ }^{\circ} \mathrm{C}$ under Ar. After stirring for $90 \mathrm{~min}$ at the same temperature, the reaction mixture was quenched with a saturated $\mathrm{NH}_{4} \mathrm{Cl}$ solution. The organic layer was separated and the aqueous layer was extracted with diethyl ether. The organic layer was washed with water and brine, dried with $\mathrm{MgSO}_{4}$ and concentrated in vacuo. The crude product was purified by chromatoghraphy in silica gel impregnated with $\mathrm{AgNO}_{3}$ eluting with pentane / diethyl ether (2:1) to give $0.067 \mathrm{~g}(55 \%)$ of the $(R)-7,15$-hexadecadien-4-olide, $[(R)-4]$. The spectroscopic data agree with those of $(S)-\mathbf{4}$. $[\alpha]_{\mathrm{D}}^{25}:+35.1\left(c=0.5, \mathrm{CHCl}_{3}\right)$.

\section{Enantiomeric purity of (S)-4 and (R)-4}

Compound (S)-4 and $(R)-\mathbf{4}$ were hydrogenated to the corresponding 4-hexadecanolide by stirring in $\mathrm{CH}_{3} \mathrm{OH}$ for $1 \mathrm{~h}$ under hydrogen atmosphere in the presence of catalytic amount of $\mathrm{Pd} / \mathrm{C}$. The solution was filtered through a short silica gel pad and directly injected in a gas chromatograph equipped with a Chirasil-DEX CD (Crompack) chiral phase capillary column. Separation of enantiomers was performed using the following gradient temperature program $145^{\circ} \mathrm{C}$ (130 min) to $155^{\circ} \mathrm{C}$ (30 min) at $1^{\circ} \mathrm{C} \mathrm{min}{ }^{-1}$ gradient. Carrier gas pressure $\left(\mathrm{H}_{2}\right)$ was $60 \mathrm{kPa}$. The injector and detector temperatures were maintained at $220^{\circ} \mathrm{C}$. The hydrogenated $(S)-\mathbf{4}$ and $(R)-\mathbf{4}$ were identified by their mass spectra. MS (m/z) (\%rel): 28 (100), 29 (53), 41 (47), 43 (47), 55 (48), 57 (33), 69 (30), 83 (24), 85 (83) 254 (1).

\section{Acknowledgements}

The authors thank FAPESP, CNPq and CAPES for support.

\section{References}

1. Leal, W. S.; Kuwahara, S.; Ono, M.; Kubota, S.; Bioorg. Med. Chem. 1996, 4, 315; Tumlinson, J. H.; Klein, M. G.; Doolittle, R. E.; Ladd, T. L.; Proveax, A. T.; Science 1977, 197, 789; Mori, K.; Acc. Chem. Res. 2000, 33, 102.

2. May, W. A.; Peterson, R. J.; Chang, S. S.; J. Food Sci. 1978, 43, 1248; Vlass, A.; Julius, H.; (Unilever N. V.) EPO 473 842, 1992; Brenna, E.; Fuganti, C.; Serra, S.; Tetrahedron: Asymmetry 2003, 14, 1.

3. Bourdineaud, J. P.; Ehret, C.; Petrzilka, M.; (Givaudan-roure International S. A.) WO 94/07887 A1, 1994.

4. Lino, Y.; Tanaka, A.; Yamashita, K.; Agric. Biol. Chem. 1972 , 36, 2506.

5. For some recent examples see: Nishikori, H.; Ito, K.; Ktsuki, T.; Tetrahedron: Asymmetry 1998, 9, 1165; Upadhya, T. T.; Gurunath, S.; Sudalai, A.; Tetrahedron: Asymmetry 1999, 10, 2899; Johnson, D. V.; Fischer, R.; Griengl, H.; Tetrahedron 2000, 56, 9289; Dumeunier, R.; Markó, I. E.; Tetrahedron Lett. 2000, 41, 10219; Leroy, B.; Dumeunier, R.; Markó, I. E.; Tetrahedron Lett. 2000, 41, 10215; Suzuki, K.; Shogi, M.; Kobayashi, E.; Inomoto, K.; Tetrahedron: Asymmetry 2001, 12, 2789; Kamal, A.; Sandbhor, M.; Shaik, A. A.; Tetrahedron: Asymmetry 2003, 14, 1575; Koul, S.; Singh, B.; Tarreja, S. C.; Qazi, G. N.; Tetrahedron 2003, 59, 3487; Tarver, J. E.; Joullieé, M. M.; J. Org. Chem. 2004, 69, 815; Garbe, L.; Tressl, R.; Helv. Chim. Acta 2004, 87, 180.

6. Clososki, G. C.; Missio, L. J.; Comasseto, J. V.; INPI Patente PI 0.303.909-9, 2003; Clososki, G. C.; Costa, C. E.; Missio, L. J.; Cass, Q. B.; Comasseto, J. V.; Synthetic Commun. 2004, 34, 817.

7. Missio, L. J.; Comasseto, J. V.; Tetrahedron: Asymmetry 2000, 11, 4609.

8. Clososki, G. C.; Missio, L. J.; Comasseto, J. V.; Synthetic Commun. 2004, 34, 2371.

9. Leal, V. S.; Kuwahara, S.; Ono, M.; Kubota, S.; Bioorg. Med. Chem. 1996, 4, 315.

10. Nakayama, T.; Mori, K.; Liebigs Ann. Recueil 1997, 839.

11. Mori, K.; Chem. Commun. 1997, 1153.

12. Gutman, A. L.; Bravdo, T.; J. Org. Chem. 1989, 54, 4263.

Received: March 31, 2004

Published on the web: October 1, 2004

FAPESP helped in meeting the publication costs of this article. 